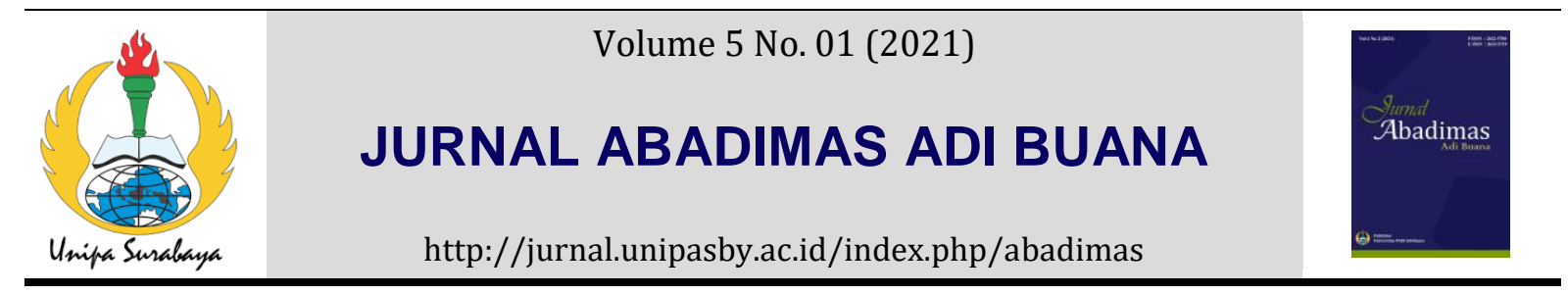

\title{
PEMASARAN ONLINE DENGAN MEMANFAATKAN PLATFORM MOBILE MARKETPLACE SHOPEE DAN STRATEGI MENINGKATKAN PENJUALAN DI MASA PANDEMI COVID DI SMK IPIEMS SURABAYA
}

\author{
Novianto Eko Nugroho ${ }^{1 *}$, Krido Eko Cahyono², Okto Aditya Suryawirawan ${ }^{3}$ \\ ${ }^{1}$ Sekolah Tinggi Ilmu Ekonomi Indonesia (STIESIA) Surabaya \\ *Email: noviantoekonugroho@stiesia.ac.id
}

\begin{tabular}{|c|c|}
\hline Informasi Artikel & Abstrak \\
\hline $\begin{array}{l}\text { Diterima: 26-04-2021 } \\
\text { Disetujui: 14-06-2021 } \\
\text { Dipubikasikan: 14-07- } \\
2021\end{array}$ & $\begin{array}{l}\text { Dampak pandemi virus corona (covid-19) dirasakan disegala sendi } \\
\text { kehidupan masyarakat khususnya usaha mikro, kecil, dan menengah } \\
\text { (UMKM). Melalui berbagai kegiatan pelatihan dan pendampingan yang } \\
\text { meliputi pemanfaatkan pemasaran online dan strategi peningkatan } \\
\text { penjualan adalah wujud nyata dan kongkrit dalam usaha meningkatkan } \\
\text { kesadaran berwirausaha dikalangan siswa/i SMK IPIEMS Surabaya. Tujuan } \\
\text { dari realisasi Kegiatan Pengabdian kepada Masyarakat melalui Pelatihan } \\
\text { dan Pendampingan Pemasaran Online dengan Memanfaatkan Platform } \\
\text { Mobile Marketplace Shopee dan Strategi Meningkatkan Penjualan di Masa } \\
\text { Pandemi Covid di SMK IPIEMS Surabaya adalah memberikan wawasan } \\
\text { dan pemahaman akan pentingnya kemampuan dalam melakukan pemasaran } \\
\text { secara online dan peningkatan penjualan barang pada para siswa/i SMK } \\
\text { IPIEMS Surabaya agar apabila lulus menjadi wirausaha. Selain dosen dari } \\
\text { Sekolah Tinggi Ilmu Ekonomi Indonesia Surabaya selaku pelaksana } \\
\text { kegiatan Pengabdian kepada Masyarakat ini, penyuluhan dan } \\
\text { pendampingan yang dilakuan juga melibatkan mitra strategis yaitu Shopee } \\
\text { Indonesia. Hasil yang diperoleh dari kegiatan pelatihan dan pendampingan } \\
\text { ini adalah pemahaman siswa/i terhadap pemasaran online Platform Mobile } \\
\text { Marketplace dan strategi peningkatan penjualan, dalam rangka } \\
\text { meningkatkan nilai produk dan omset penjualan yang dihasilkan. } \\
\text { Abstract }\end{array}$ \\
\hline
\end{tabular}

Keywords :

Marketing, Platform

Marketplaces, Sales,

Shopee
The impact of the corona virus pandemic (covid-19) is felt in all aspects of community life, especially Micro, Small and Medium Enterprises (MSMEs). Through various training and mentoring activities which include the use of online marketing and sales improvement strategies is a concrete and concrete manifestation in an effort to increase entrepreneurial awareness among students of SMK IPIEMS Surabaya. The purpose of the realization of Community Service Activities through Online Marketing Training and Assistance by Utilizing the Shopee Mobile Marketplace Platform and Strategies to Increase Sales in the Covid Pandemic Period at SMK IPIEMS Surabaya is to provide insight and understanding of the 
importance of the ability to do online marketing and increase sales of goods to consumers. students of SMK IPIEMS Surabaya so that when they graduate they become entrepreneurs. In addition to lecturers from the School of Economics Indonesia Surabaya as the implementer of this Community Service activity, the counseling and mentoring carried out also involves strategic partners, namely Shopee Indonesia. The results obtained from this training and mentoring activity are students' understanding of the online marketing of the Mobile Marketplace Platform and sales improvement strategies, in order to increase product value and the resulting sales turnover.

\section{PENDAHULUAN}

Eksistensi dunia pendidikan dalam menyambut era society 5.0 memiliki peran penting dalam meningkatkan kualitas SDM yang dibekali tidak hanya hard skill akan tetapi soft skill yang mumpuni agar dapat bersaing. Terdapat beberapa pihak yang memiliki peranan penting seperti pemerintah, Organisasi Masyarakat (Ormas) dan seluruh masyarakat juga turut berkontribusi dalam menyambut era society 5.0 mendatang. Upaya yang dilakukan dalam menyambut era society 5.0 ini satuan pendidikan sangat dibutuhkan dalam mendukung perubahan paradigma pendidikan diantaranya pendidik meminimalkan peran sebagai learning material provider, pendidik menjadi penginspirasi bagi tumbuhnya kreativitas peserta didik dan memiliki keterampilan dibidang digital dan berpikir kreatif.

SMK IPIEMS Surabaya merupakan salah satu SMK IPIEMS yang terbaik di Surabaya. SMK IPIEMS Surabaya berdiri sejak tanggal 5 Agustus 2009. Sekolah ini beralamat di JL. Raya Menur No. 125, Manyar Sabrangan, Kec. Mulyorejo, Kota Surabaya Prov. Jawa Timur. SMK IPIEMS Surabaya sudah cukup terkenal di masyarakat, selain kualitasnya yang bagus, sudah terbukti mencetak lulusan yang berprestasi dan mempunyai daya saing. Sebagai sekolah yang telah diakui kini SMK IPIEMS Surabaya telah terakreditasi A (https://bansm.kemdikbud.go.id/akreditasi). Sekolah yang berada di Kota Surabaya ini merupakan sekolah dengan prospek yang bagus. Sekolah ini berstatus sebagai sekolah swasta di bawah Yayasan Pendidikan IPIEMS dan dilihat dari lokasi yang strategis dan kondusif dalam lingkungan pendidikan untuk melakukan kegiatan belajar mengajar.Siswa/siswi SMK IPIEMS Surabaya memberikan kontribusi prestasi diberbagai perlombaan tingkat Lokal, Regional maupun Nasional. Hal ini menunjukkan bahwa SMK IPIEMS Surabaya selain berprestasi dalam bidang akademik juga berprestasi dalam mengembangkan potensi siswa dalam bidang non-akademik.

Sesuai dengan kurikulum terbaru SMK mengacu pada kurikulum 2018 melalui kurikulum ini diharapkan siswa Program keahlian Otomatisasi Tata Kelola Perkantoran (OTKP) SMK IPIEMS Surabaya memiliki kompetensi keahlian produk kreatifitas dan kewirausahaan. Untuk memenuhi kompetensi tersebut, siswa/i SMK kelas $\mathrm{X}$ (sepuluh) memperoleh mata pelajaran simulasi dan komunikasi digital. Pada mata pelajaran ini siswa/i mempelajari komunikasi dalam Jaringan Daring (Online), penerapan komunikasi daring, kelas daring (online), pembelajaran melalui kelas daring 
(Online), presentasi video, presentasi video untuk branding dan marketing, simulasi visual, aplikasi pengolah simulasi visual tahap praproduksi, aplikasi pengolah simulasi visual tahap produksi, aplikasi pengolah simulasi visual tahap, pascaproduksi, buku digital, format buku digital dan publikasi buku digital. Untuk dapat mendukung siswa/i menguasai kompetensi tersebut, maka dibutuhkan ilmu pemasaran online.

Dengan ada kebutuhan pemahaman tentang pemasaran online ini, maka tim dosen pengabdian kepada masyarakat akan memberikan tambahan pengetahuan dan wawasan secara teoritis dan praktek dalam bidang kewirausahaan. "Pemasaran adalah aktivitas, serangkaian intuisi, dan proses menciptakan, mengkomunikasikan, menyampaikan, dan mempertukarkan tawaran (offerings) yang bernilai bagi pelanggan, klien, mitra, dan masyarakat umum.(American Marketing Association yang dikutip oleh Fandy Tjiptono dan Anastasia, 2016:3)". Diera society 5.0 dengan pesat perkembangan teknologi informasi dan adanya pandemi covid 19 saat ini kebutuhan pemanfaatan web atau mobile platform market place dalam pemasaran online lebih efektif dan efisien melalui pemasaran online menyebabkan jangkauan menjadi lebih luas dan tidak terbatas sangat menguntungkan bagi penjual (seller) dan pembeli (buyer) dan mudah menemukan produk yang diinginkan / dibutuhkan dimana pun mereka berada selama terdapat internet untuk mengaksesnya.

"Pemasaran onlinel internet marketing/ online marketing merupakan salah satu bentuk $e$ marketing yang menggambarkan penggunaan website untuk memperkuat usaha pemasaran, khususnya prosmosi yang dilakukan oleh perusahaan, penggunaan website untuk melakukan lelang produk seperti eBay yang mengalami perkembangan pesat melalui komunikasi dari mulut ke mulut, dan penerapan $e C R M$ dalam membangun dan mengelola hubungan dengan pelanggan (Dehkordi et al, 2012).” Menurut Andrian (2019) menjelaskan, "Digital Marketing adalah merupakan suatu kegiatan pemasaran atau promosi sebuah brand atau produk menggunakan media digital atau internet untuk menarik konsumen dan calon konsumen secara cepat. dengan penerimaan teknologi dan internet di masyarakat sangat luas, sehingga tidak heran kegiatan pemasaran secara digital dijadikan pilihan utama oleh perusahaan-perusahaan." Menurut Arimbi (2020) bahwa "Usaha yang dilakukan untuk menjangkau calon pembeli dengan mengenalkan merek dagang atau jasa melalui media digital dapat diartikan sebagai pemasaran digital, dengan penggunaan media digital dalam memasarkan produknya, pengusaha dapat memasarkan produk secara tepat waktu, pribadi, serta lebih relevan." Menurut Farell et al. (2019), telah dilakukan sosialisasi dan pelatihan pemanfaatan digital marketing dalam pengembangan pemasaran dan kewirausahaan UKM di Kota Sawahlunto dengan fokus pada upaya menghasilkan cara pemasaran dari sebuah produk hasil pemanfaatan bahan yang ada di sekitar masyarakat."

Dalam melakukan transaksi secara online menggunakan media online e-Business atau dikenal dengan E-Commerce, "e-Commerce adalah rangkaian kegiatan usaha perdagangan yang sebagian atau seluruhnya menggunakan media internet sebagai media komunikasinya. 
(Nufransa,2014)". Dalam hal ini jenis e-Commerce jenis mobile marketplace Shopee merupakan salah satu marketplace yang pertama kali dijalankan SEA Group mengusung mobile marketplace Bisnis C2C (customer to customer). Pada Desember 2015 shopee resmi diperkenalkan di Indonesia di bawah naungan PT Shopee International Indonesia.

Upaya peningkatan penjualan barang secara online menggunakan mobile marketplace, perlu adanya strategi penjualan yang terencana dengan baik dan fokus agar tren penjualan mengalami peningkatan secara terus menerus. Strategi peningkatan penjualan yang digunakan adalah strategi promosi dengan copywriting, strategi limited edition, strategi promosi bundling package, strategi voucher diskon dengan maksimum pembelian dan strategi permainan harga. Berdasarkan penjabaran tersebut diatas diharapkan melalui kegiatan pengabdian kepada masyarakat ini dilakukan untuk para siswa/i SMK IPIEMS Surabaya memahami dan mampu memanfaatkan media mobile marketplace shopee untuk berjualan dan membantu meningkatkan penjualan secara online.

\section{METODE}

Metode pelaksanaan kegiatan Pengabdian kepada Masyarakat (PKM) yang dilakukan tim dosen Sekolah Tinggi Ilmu Ekonomi Indonesia Surabaya sebagai berikut :

a. Survei Tempat Pelaksanaan Kegiatan

Tim Dosen pelaksanaan kegiatan Pengabdian kepada Masyarakat (PKM) berkoordinasi dengan mahasiswa dan Wakil Kepala Sekolah Humas SMK IPIEMS Surabaya untuk menggali informasi dan memetakan mengenai kondisi geografis kondisi siswa/i sekolah untuk mendapatkan informasi lokasi serta permasalahan yang dihadapi.

b. Persiapan Sarana dan Prasarana

Kegiatan ini dilakukan guna mempersiapkan dan memfasilitasi kebutuhan para siswa/i dengan menyediakan sarana dan prasarana demi tercapainya target Pengabdian kepada Masyarakat.

c. Pelaksanaan Kegiatan Pengabdian kepada Masyarakat

Setelah melakukan survey dan persiapan sarana dan prasarana, maka pelaksanaan kegiatan dilaksanakan oleh ketua pelaksana beserta anggota tim dan beberapa mahasiswa. Kegiatan berupa pelatihan dan pendampingan pemasaran online dengan pemanfaatan mobile marketplace shopee dan strategi meningkatkan penjualan dalam bentuk pertemuan secara daring dengan siswa kelas 2 SMK IPIEMS Surabaya.

d. Monitoring Kegiatan Pengabdian kepada Masyarakat

Kegiatan monitoring kegiatan pengabdian kepada masyarakat salah satu upaya untuk meninjau perkembangan siswa/i terhadap kegiatan Pengabdian kepada Masyarakat yang telah dilakukan sebelumnya dengan harapan dapat dilaksanakan sesuai dengan pelatihan yang diperoleh para siswa/i dari yang telah dijelaskan tim dosen dan mahasiswa.

e. Evaluasi Kegiatan Pengabdian kepada Masyarakat 
Evaluasi kegiatan pengabdian kepada masyarakat bertujuan untuk memahami pola pemahaman siswa/i terhadap pelatihan yang diperoleh dari pelaksana kegiatan. Hasil ini diharapkan siswa/i mampu dan termotivasi untuk membuat toko online menggunakan media mobile atau web marketplace shopee dalam menjalankan usaha secara online dan mampu meningkatkan penjualan dari usaha yang telah dirintis.

\section{HASIL DAN PEMBAHASAN}

Kegiatan pengabdian kepada masyarakat pelatihan dan pendampingan pemasaran online dengan memanfaatkan marketplace dan strategi meningkatkan penjualan terdiri dari beberapa kegiatan, yaitu dimulai dengan pengenalan tim dosen dan mahasiswa kegiatan Pengabdian kepada Masyarakat STIESIA Surabaya dan penjelasan tentang pemasaran online atau $e$-marketing melalui e-Commerce berbasis web / mobile marketplace khususnya aplikasi Shopee, kemudian dilanjutkan penjelasan materi strategi peningkatan penjualan di masa pandemi covid 19 dan terakhir tim ahli dari PT. Shopee International Indonesia yang diwakili Community field Staff Surabaya yang menjelaskan profile dan fitur bisnis di shopee. Setelah menerima materi siswa/i mempraktikan langsung di aplikasi shopee setiap siswa/i melalui web/mobile shopee mulai membuat akun penjual (seller), administrasi penjual sampai dengan mendesign dan mengupload produk di web/mobile marketplace shopee. Sebelum mengakhiri pelatihan, para siswa/i diminta menyampaikan kesan dan pesan tentang pelatihan dan pendampingan yang diberikan serta siswa kegiatan pengabdian kepada masyarakat dengan menuliskan rencana usaha toko online sesuai kebutuhan dan prospek target pasar yang diinginkan.

Tabel 1. Hasil Kegiatan Pengabdian Masyarakat

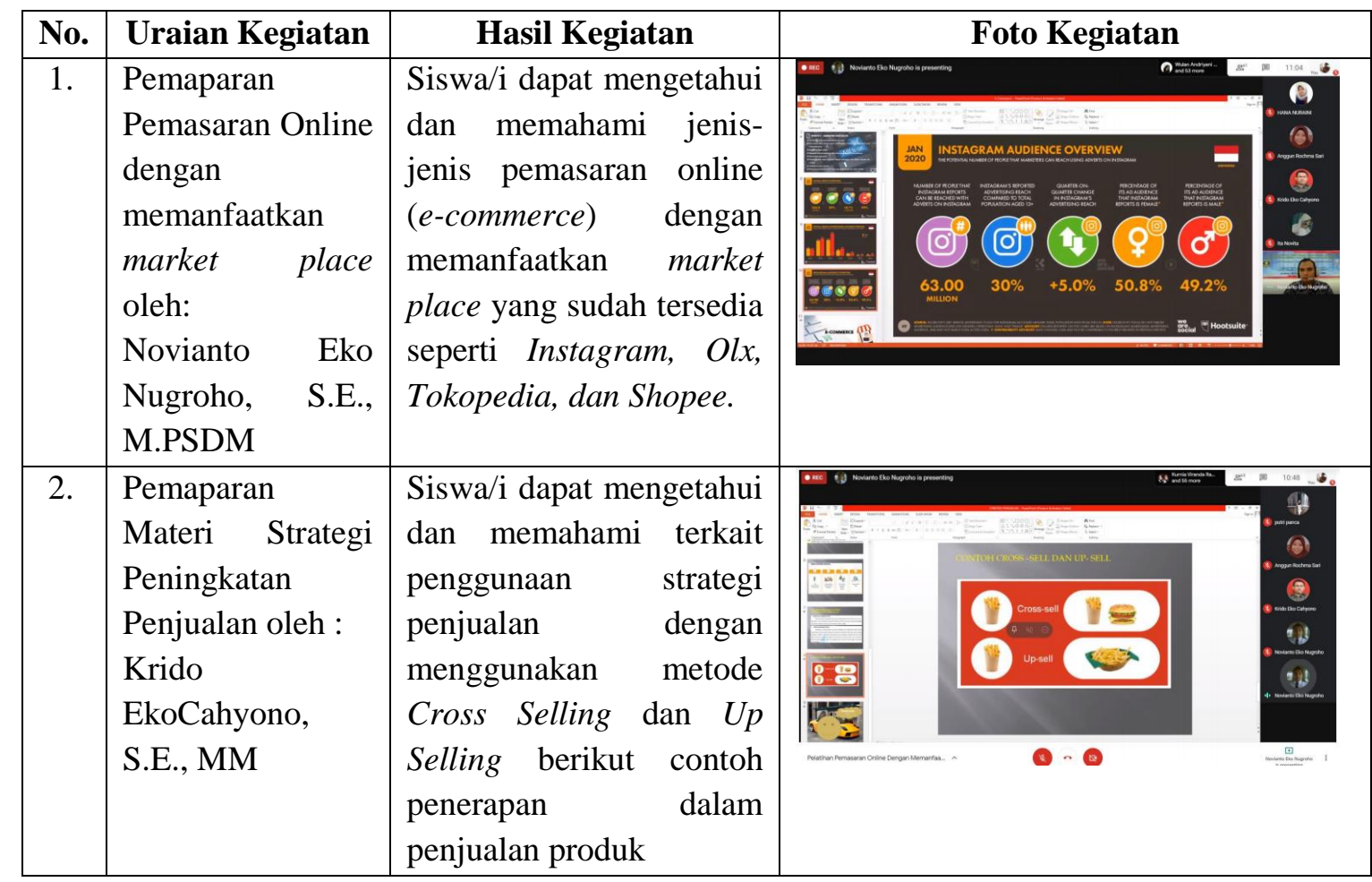




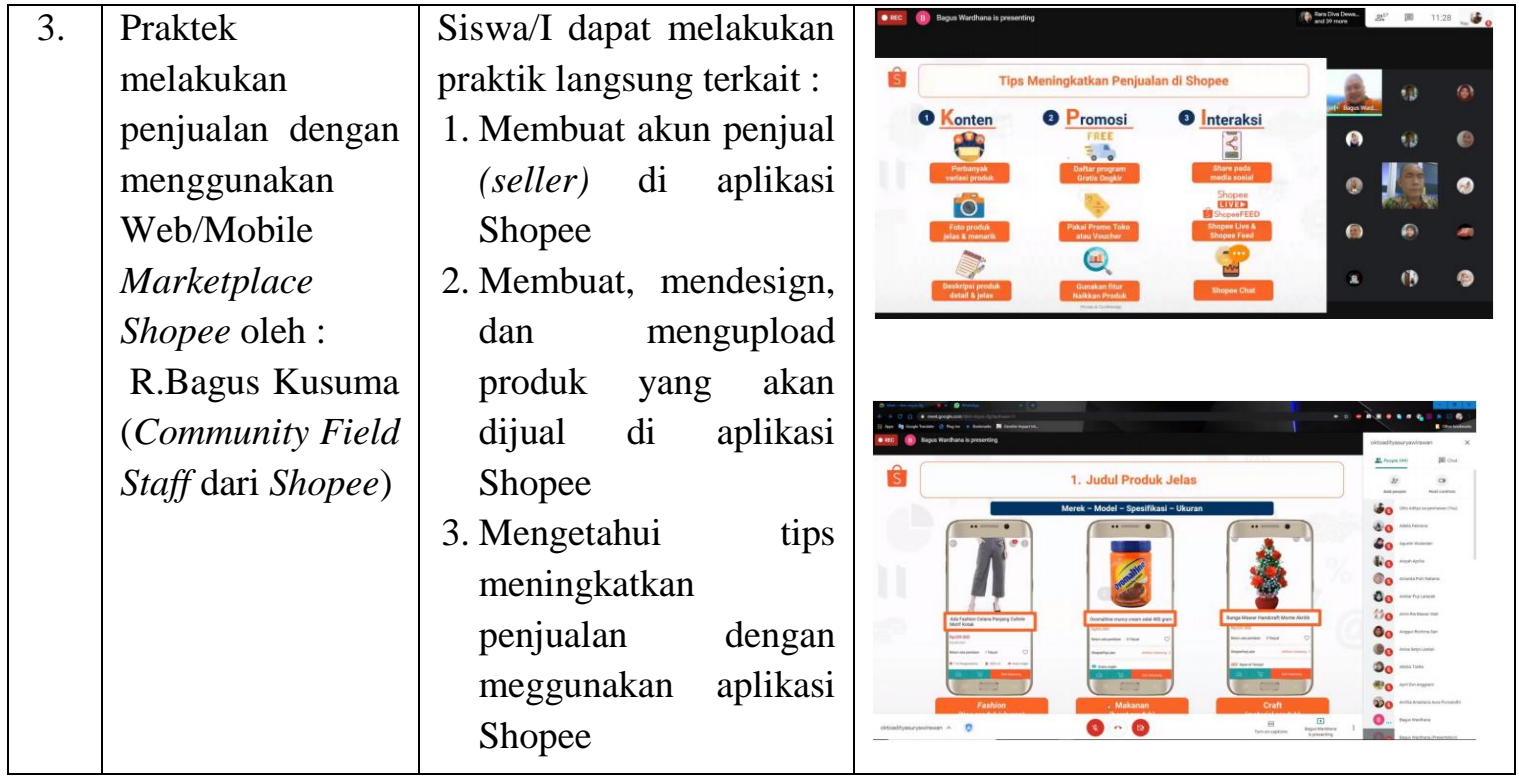
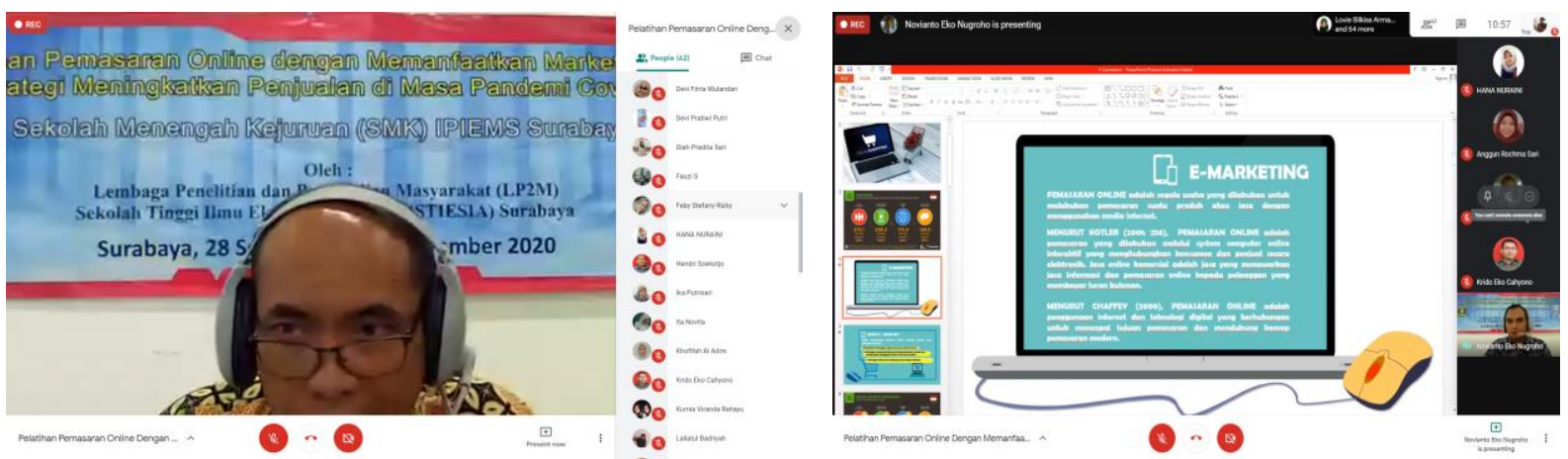

Gambar 1. a. Pembukaan kegiatan oleh Ketua Pelaksana, b. Penyampaian Materi Pemasaran Online
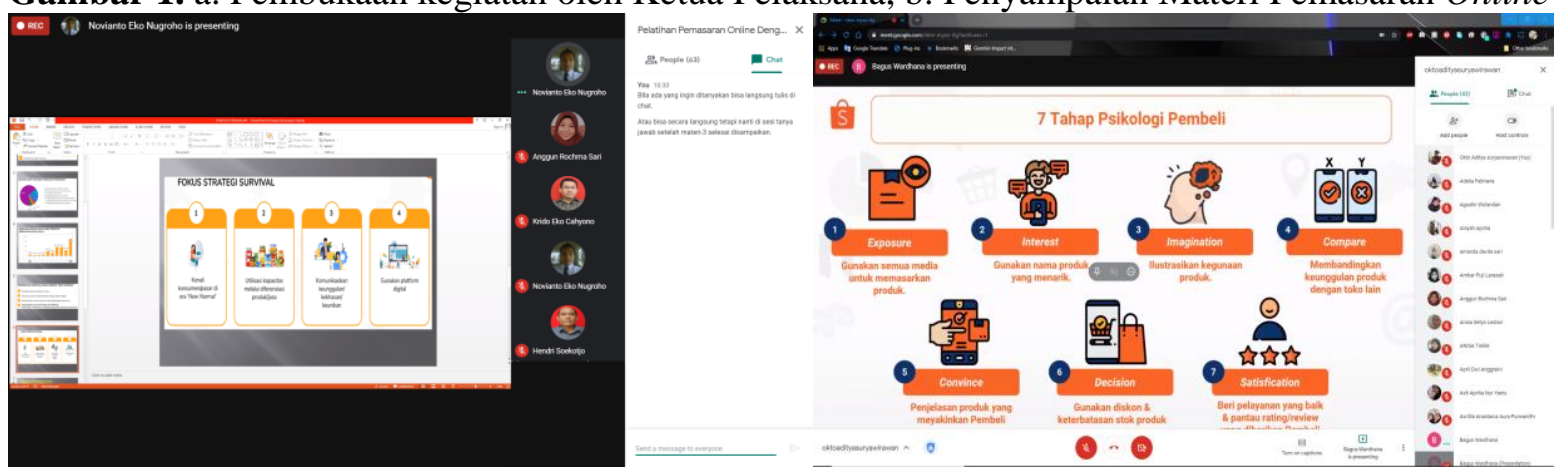

Gambar 2. a. Penyampaian Materi Strategi Penjualan, b. Penyampaian Materi Marketplace Shopee

Pelaksanaan pengabdian kepada masyarakat dilakukan secara daring menggunakan aplikasi googlmeet dibagi 2 sesi pada hari Kamis, tanggal 11 Oktober 2020, pukul 10.00 WIB dan pada hari Sabtu, 7 November 2020 bertempat di Kampus STIESIA Surabaya dan rumah masing-masing peserta. Kegiatan ini diikuti oleh 43 siswa/i SMK IPIEMS Surabaya, 4 orang narasumber dan 2 orang mahasiswa sebagai pendamping yang ikut terlibat aktif mendukung kelancaran pada kegiatan Pengabdian kepada Masyarakat.

Inti pembahasan materi pada kegiatan pelatihan dan diskusi permasalahan pada pelaksanaan 
kegiatan pengabdian kepada masyarakat yang dilakukan meliputi :

1. Implementasi pemasaran produk secara online (e-marketing) melalui e-commerce marketplace yang menggunakan prinsip business to consumer (B2C) dan consumer to consumer (C2C) yang efektif dan efisien dalam memasarkan dan menjual produk langsung dengan konsumen secara virtual mulai pesanan barang, pembayaran, sampai dengan proses pengiriman barang yang terintegrasi dalam sistem yang dikelola perusahaan marketplace.

2. Implementasi strategi penjualan produk melalui mentoring dari tim dosen dan tim shopee dalam membuat toko online yang menarik dan diminati konsumen karena beragamnya variasi produk dan promosi produk yang berkelanjutan.

3. Implementasi pemanfaatan marketplace dalam mengembangkan usaha lebih kreatif dan inovatif dalam menampilkan penawaran produk secara virtual yang menawarkan layanan secara online mempertemukan ketersediaan barang dari penjualan dan kebutuhan barang dari konsumen dengan jaminan keamanan transaksi dari perusahaan pengelola toko online yaitu marketplace.

\section{KESIMPULAN}

Berdasarkan realisasi pelaksanaan kegiatan pengabdian kepada masyarakat kerjasama SMK IPIEMS Surabaya dengan obyek para siswa/i kelas 2 Program keahlian Otomatisasi Tata Kelola Perkantoran (OTKP) terkait dengan implementasi keahlian produk kreatifitas dan kewirausahaan dengan materi pemasaran online memanfaatkan marketplace dan strategi penjualan dalam kondisi covid 19, maka dapat diperoleh kesimpulan berikut :

a. Para siswa/i mampu memahami jenis-jenis pemasaran online (e-commerce) dengan memanfaatkan market place yang sudah tersedia seperti Instagram, Olx, Tokopedia, dan Shopee.

b. Para siswa/i mampu memahami terkait penggunaan strategi penjualan dengan menggunakan metode Cross Selling dan Up Selling berikut contoh penerapan dalam penjualan produk.

c. Siswa/i mampu melakukan praktik langsung terkait membuat akun penjual (seller) di aplikasi Shopee, membuat, mendesign, dan mengupload produk yang akan dijual di aplikasi Shopee dan mengetahui tips meningkatkan penjualan dengan menggunakan aplikasi Shopee.

\section{UCAPAN TERIMAKASIH}

Untuk keberhasilan dan kelancaran program pengabdian kepada masyarakat yang telah dilakukan pada siswa/i SMK IPIEMS Surabaya, tim pengabdian kepada masyakarat mengucapkan terima kasih kepada beberapa pihak yang telah mendukung penuh sebagai berikut :

1. Ketua Sekolah Tinggi Ilmu Ekonomi Indonesia (STIESIA) Surabaya yang telah berkenan mengijinkan teralisasinya kegiatan pengabdian kepada masyarakat untuk tahun akademik gasal 2020-2021. 
2. Kepala Lembaga Penelitian dan Pengabdian kepada Masyarakat Sekolah Tinggi Ilmu Ekonomi Indonesia (STIESIA) Surabaya yang telah memfasilitasi teralisasinya kegiatan pengabdian kepada masyarakat untuk tahun akademik gasal 2020-2021.

3. Kepala Sekolah Sekolah Menengah Kejuruan (SMK) IPIEMS Surabaya yang telah berkenan mengijinkan dan menyediakan waktu kepada siswa/i nya untuk teralisasina kegiatan pengabdian kepada masyarakat

4. Seluruh peserta kegiatan pengabdian kepada masyarakat dari siswa/i SMK IPIEMS Surabaya atas partisipasi dan antusiasmenya mengikuti kegiatan dari awal hingga akhir

\section{DAFTAR PUSTAKA}

Andrian, S. E. (2019). Digital Marketing dan Ragam Produk pada Minat Beli Konsumen Toko Online Shopee (Studi Kasus pada Mahasiswa Prodi Manajemen Fakultas Ekonomi Universitas Bhayangkara Jakarta Raya Angkatan 2016). Ekspektra: Jurnal Bisnis dan Manajemen, 3(1), 1424.

Arimbi, D. F. (2020). Pengaruh Digital Marketing terhadap Minat Beli Konsumen (Studi Kasus pada Pengguna Aplikasi SHOPEE) (Doctoral dissertation, STIE YKPN).

Badan Akreditasi Nasional Sekolah/Madrasah. "Data Akreditasi Sekolah", bansm.kemdikbud.go.id. www. bansm.kemdikbud.go.id/akreditasi (diakses 12 April 2021).

Dehkordi, G. J., Rezvani, S., Rahman, M. S., Nahid, F. F. N., \& Jouya, S. F. (2012). A conceptual study on E-marketing and its operation on firm's promotion and understanding customer's response. International Journal of Business and Management, 7(19), 114.

Farell, G., Thamrin, T., \& Novid, I. (2019). Pelatihan Pemanfaatan Digital Marketing Dalam Pengembangan Pemasaran Dan Kewirausahaan UKM Pada Kota Sawahlunto. Suluah Bendang: Jurnal Ilmiah Pengabdian Kepada Masyarakat, 19(1), 42-47.

Munarsih, M., Akbar, M. F., Ariyanto, A., Ivantan, I., \& Sudarsono, A. (2020). Pelatihan Digital Marketing Dalam Meningkatkan Kompetensi Siswa Untuk Berwirausaha Pada Smk Muhammadiyah Parung-Bogor. Jurnal Pengabdian Dharma Laksana, 3(1), 22-28.

Napitupulu, L. H., Bako, E. N., Ars, N. R., \& Zein, T. (2018). A Multimodal Analysis of Advertisement of Online Marketplace Shopee. KnE Social Sciences, 452-460.

Raniswara, D. A. (2021). LKP: Pemanfaatan Digital Marketing (SHOPEE) untuk Membantu Meningkatkan Kegiatan Pemasaran Secara Online pada UMKM Miss Batik Collection (Doctoral dissertation, Universitas Dinamika).

Sakti, N. W., \& Kom, S. (2014). Buku Pintar Pajak E-Commerce. VisiMedia.

Silmina, E. P., \& Linawati, S. L. (2018). Pelatihan Internet Marketing Pada Siswa Smk Muhammadiyah 2 Yogyakarta. Dharma Raflesia: Jurnal Ilmiah Pengembangan dan Penerapan IPTEKS, 16(2).

Tjiptono, F. (2020). Pemasaran esensi \& aplikasi. 